\title{
Prevalence of Refractive Errors among Medical Students and Identification of Associated Factors
}

Saadia Maqbool, Abdul Rehman Rizwan, Iram Manzoor, Ali Qais, Aleena Furqan, Abdul Rehman

\begin{abstract}
Objective: To determine the prevalence of refractive errors among medical students and identify associated factors.

Study Design: Analytical, cross-sectional study.

Place and Duration of Study: The study was conducted in the Department of Community Medicine at Akhtar Saeed Medical and Dental College, Lahore from September 2020 to December 2020.

Materials and Methods: The study included 300 medical students using convenience sampling technique. A self- structured pre- tested questionnaire was used. All medical students including MBBS, BDS, Pharm -D and allied health sciences were included in the study. Those students who did not give consent were excluded from the study. Data analysis was done with SPSS version 23. Chi square test of significance was applied to find association between the variables and $p$-value $<0.05$ was considered statistically significant.

Results: Refractive error was observed in 203 students (67.7\%). The commonest refractive error was myopia (37\%) followed by hypermetropia (23.7\%) and astigmatism (7\%). The prevalence of refractive errors was significantly associated with positive family history $(p$ value $=<.001)$, family income per month ( $p$ value $=0.01$ ) and mobile use per day ( $p$ value=0.001). Higher percentage of refractive error $(70.6 \%)$ was reported by participants who were comfortable with light in which they study ( $p$ value $=0.03$ ).

Conclusion: The prevalence of refractive error was $67.7 \%$ among medical students, and myopia was the most prevalent refractive error. Refractive errors were significantly associated with positive family history, family income and mobile use per day.
\end{abstract}

Key Words: Myopia, Medical Student, Refractive Error, Risk Factors.

How to cite this: Maqbool S, Rizwan AR, Manzoor I, Qais A, Furqan A, Rehman A. Prevalence of Refractive Errors among Medical Students and Identification of Factors Associated. Life and Science. 2021;2(4): 164-168. doi: http://doi.org/10.37185/LnS.1.1.184

This is an Open Access article distributed under the terms of the Creative Commons Attribution License (http://creativecommons.org/licenses/by/4.0), which permits unrestricted use, distribution, and reproduction in any medium, provided the original work is properly cited.

\section{Introduction}

Globally, refractive errors are the prevalent cause for vision impairment and the second most common cause of blindness. ${ }^{1}$ According to World Health Organization (WHO), one billion people have a vision impairment. Uncorrected refractive error has been documented as one of the root causes of moderate or severe vision impairment or blindness in $\mathbf{1 2 3 . 7}$ million individuals. ${ }^{2}$ Magnitude of refractive errors is

Department of Community Medicine

Akhtar Saeed Medical and Dental College, Lahore

Correspondence:

Dr. Saadia Maqbool

Department of Community Medicine

Akhtar Saeed Medical and Dental College, Lahore

E-mail:maqboolsaadia@yahoo.com

Funding Source: NIL; Conflict of Interest: NIL

Received: Mar 05, 2021; Revised: May 05, 2021

Accepted: May 28, 2021 quite high in our country and about 27.1 million persons aged 16-39 years are suffering from refractive errors. ${ }^{3}$

Globally, the prevalence of refractive errors, specifically myopia, is increasing at an alarming pace. Myopia is affecting $27 \%$ of the world population, with an incidence of $32.9 \%$ in adult population of Asia. ${ }^{4}$ In Pakistan, myopia affects $36.5 \%$ of adults and $42.2 \%$ of the pediatric population. ${ }^{5}$ The global incidence of hypermetropia is recorded as $30.6 \%$, with regional incidence of $38.9 \%$ in Asia. ${ }^{6}$ It has an occurrence of $10.14 \%$ among Pakistani adults. ${ }^{7}$ In Southeastern Asia, the EPP of astigmatism is about $44.8 \%{ }^{6}$

Uncorrected refractive errors are known to have many social consequences in addition to the health risks. The social ramifications may include isolation, 
reduced educational and employment opportunities, increased morbidity, economic distress and overall quality of life. ${ }^{8}$

Prevention or corrective treatment is possible in $80 \%$ of the causes of visual impairment. The WHO and 20 International Non-Governmental Organizations (INGOs) launched the global initiative, "Vision 2020," for reducing preventable blindness. Refractive errors are a priority for this global initiative Vision 2020: the Right to Sight. ${ }^{9}$

Academically active professionals are some of the prime candidates for this condition. ${ }^{10}$ This group encounters increased electronic display screens and spends long hours in reading and doing work with focused eyes. For any developing country, medical students are regarded as a valuable future human resource. The ocular health of the young generation is paramount to their development and by extension, to the future of the nation. The increasing frequency of refractive errors in the young population threatens to add to the economic burden. ${ }^{11}$ Therefore, knowledge about the influencing factors of refractive errors would be helpful in planning a public health strategy for the prevention.

In Pakistan, refractive errors are often neglected. There is paucity of data on the current situation in medical students in Pakistan. This study aimed to assess the burden of refractive errors in students of the medical profession and related factors.

\section{Materials and Methods}

This analytical cross-sectional study was conducted in the Department of Community Medicine at Akhtar Saeed Medical and Dental College, Lahore from September 2020 to December 2020. Raosoft sample size calculator was used for sample size estimation. Calculated sample size was 259, keeping prevalence of refractory errors as $21.8 \%$, margin of error at $5 \%$ and confidence level at $95 \% .{ }^{12}$ After $10 \%$ increase to cover missing data and rounding off, final sample size came out to be 300 participants. Approval from ethical review board was taken (IRB certificate no M$18 / 047 /-C M)$. Convenience sampling technique was used. Students from various medical programmes (MBBS, BDS, Pharma-D and Allied Health Sciences), both male and female who were willing to participate were included. Those who denied giving consent were excluded. A self-constructed, pretested questionnaire was used which included the socio-demographic variables (age, gender, medical programme, family income per month and family history of refractory errors). Frequency of exercise, time spent on using computer and mobile and watching television, no of hours spent per day in reading/studying, comfort with light in which participants study and type of light used were also considered. Research questionnaire was designed after extensive literature search based upon questions used in previous studies. After review by two public health specialists and a biostatistician, it was pilot tested on 20 students and modified accordingly.

Data were analyzed using SPSS Version 23. Frequencies and percentages were used to present qualitative data. Mean and standard deviation were calculated for quantitative data. Chi square test of significance was applied to find association between independent and dependent variables. A $p$-value of $<$ 0.05 was considered statistically significant.

\section{Results}

The mean age of the study participants was $21.8 \pm$ 1.79 years. Among total participants, 197 (65.7\%) were MBBS students, 45 (15\%) were BDS students, $37(12.3 \%)$ were Pharm -D students and 21 (7\%) were Allied Health Sciences students. Out of the 300 study participants, 203(67.7\%) participants had refractive errors. The most prevalent refractive error was Myopia, reported by 111 (37\%) students. Hypermetropia was reported by 71 (23.7\%) and astigmatism by 21 (7\%) students.

Prevalence of refractive errors was higher among females as $81(72.9 \%)$ had refractive error as compared to 122 (64.5\%) males. Highest percentage (76\%) of refractive errors was observed in those whose family income was more than one million per month ( $p$ value $=0.01$ ). Significant association was observed between presence of refractive errors and positive family history ( $p$ value $=<0.001$ ). About $76.6 \%$ participants having refractive errors, had family members who use glasses or contact lens. Parents of $74 \%$ students with refractive errors, use glasses or lens.

Participants with refractive errors were found to be more conscious about light in which they study. Higher percentage of refractive errors was noted in participants $(70.6 \%)$ who were comfortable with 
light in which they study ( $p$ value $=0.03$ ). Refractive error was more common in students who study in bulb light, as compared to those who study in tube light or LED light, although it was not statistically significant.

Those who use mobile for more than 3 hours per day, have more chances of refractive errors. Among students who used mobile for more than 3 hours per day, $74.7 \%$ students had refractive errors. Statistically significant association was observed $(p=0.001)$ between both variables. Results are shown in Table no 1 and 2.

\begin{tabular}{|c|c|c|c|}
\hline \multirow{2}{*}{\multicolumn{4}{|c|}{ Percentage (\%) }} \\
\hline & & & \\
\hline \multicolumn{2}{|l|}{ Up to 20 years } & 74 & 24.7 \\
\hline \multicolumn{2}{|l|}{$21-24$ years } & 211 & 70.3 \\
\hline \multicolumn{2}{|l|}{25 years or more } & 15 & 5 \\
\hline \multicolumn{4}{|c|}{ Medical programme } \\
\hline \multicolumn{2}{|c|}{ MBBS } & 197 & 65.7 \\
\hline \multicolumn{2}{|l|}{ BDS } & 45 & 15 \\
\hline \multicolumn{2}{|c|}{ Pharm-D } & 37 & 12.3 \\
\hline \multicolumn{2}{|c|}{ Allied Health Sciences } & 21 & 7 \\
\hline \multicolumn{4}{|c|}{ Area of residence } \\
\hline \multicolumn{2}{|l|}{ Urban } & 243 & 81 \\
\hline \multicolumn{2}{|l|}{ Rural } & 57 & 19 \\
\hline \multicolumn{4}{|c|}{ Presence of Refractory } \\
\hline \multicolumn{2}{|l|}{ Absent } & 97 & 32.3 \\
\hline \multicolumn{2}{|l|}{ Present } & 203 & 67.7 \\
\hline \multicolumn{4}{|c|}{$\begin{array}{l}\text { Table No 2: Presence of refractive errors in relation to different } \\
\text { factors }\end{array}$} \\
\hline Factors & $\begin{array}{l}\text { Frequency } \\
\text { (\%) }\end{array}$ & $\begin{array}{l}\text { Presence of } \\
\text { Refractive Errors }\end{array}$ & $p$ value \\
\hline \multicolumn{4}{|l|}{ Gender } \\
\hline Female & $111(37)$ & $81(72.9)$ & \multirow{2}{*}{0.13} \\
\hline Male & $189(63)$ & $122(64.6)$ & \\
\hline \multicolumn{4}{|l|}{$\begin{array}{l}\text { Family income } \\
\text { per month }\end{array}$} \\
\hline $100000-300000$ & $141(47)$ & $105(74.4)$ & \multirow{6}{*}{0.01} \\
\hline$>300000-500000$ & $92(30.7)$ & $50(54.3)$ & \\
\hline$>500000-$ & $42(14)$ & $29(69)$ & \\
\hline 1000000 & $25(8.3)$ & $19(76)$ & \\
\hline \multirow{2}{*}{\multicolumn{3}{|c|}{$\begin{array}{l}\text { More than } \\
1000000\end{array}$}} & \\
\hline & & & \\
\hline \multicolumn{4}{|l|}{$\begin{array}{l}\text { Family history of } \\
\text { refractory error }\end{array}$} \\
\hline Present & $209(69.7)$ & $160(76.6)$ & \multirow{2}{*}{$<.001$} \\
\hline Absent & $91(30.3)$ & $43(47.3)$ & \\
\hline \multicolumn{4}{|l|}{$\begin{array}{l}\text { Frequency of } \\
\text { exercise }\end{array}$} \\
\hline Daily & $45(15)$ & $29(64.4)$ & \multirow{4}{*}{0.54} \\
\hline 2 days in a week & $49(16.3)$ & $31(63.3)$ & \\
\hline 3 days in a week & $46(15.3)$ & $35(76)$ & \\
\hline Never & $160(53.3)$ & $108(67.5)$ & \\
\hline
\end{tabular}

\begin{tabular}{|c|c|c|c|}
\hline \multirow{2}{*}{\multicolumn{4}{|c|}{$\begin{array}{l}\text { Hours spent } \\
\text { watching TV per } \\
\text { day }\end{array}$}} \\
\hline & & & \\
\hline Less than one & 155(51.7) & $106(68.4)$ & \multirow{5}{*}{0.45} \\
\hline hour & $81(27)$ & $52(64.1)$ & \\
\hline $1-2$ hours & $35(11.7)$ & $22(62.9)$ & \\
\hline $3-5$ hours & $29(9.7)$ & $23(79.3)$ & \\
\hline \multicolumn{3}{|l|}{$\begin{array}{l}\text { More than } 5 \\
\text { hours }\end{array}$} & \\
\hline \multicolumn{4}{|l|}{$\begin{array}{l}\text { Hours spent on } \\
\text { computer per } \\
\text { day }\end{array}$} \\
\hline Less than one & $61(20.3)$ & $44(72.1)$ & \multirow{5}{*}{0.78} \\
\hline hour & $73(24.3)$ & $50(68.5)$ & \\
\hline 1-2 hours & $95(31.7)$ & $61(64.2)$ & \\
\hline 3-5 hours & $71(23.7)$ & $48(67.6)$ & \\
\hline $\begin{array}{l}\text { More than } 5 \\
\text { hours }\end{array}$ & & & \\
\hline \multicolumn{4}{|c|}{$\begin{array}{l}\text { Hours spent } \\
\text { reading/studying } \\
\text { per day }\end{array}$} \\
\hline Less than one & $61(20.3)$ & $44(72.1)$ & \multirow{5}{*}{0.78} \\
\hline hour & $73(24.3)$ & $50(68.5)$ & \\
\hline $1-2$ hours & $95(31.7)$ & $61(64.2)$ & \\
\hline $3-5$ hours & $71(23.7)$ & $48(67.6)$ & \\
\hline $\begin{array}{l}\text { More than } 5 \\
\text { hours }\end{array}$ & & & \\
\hline \multicolumn{4}{|l|}{$\begin{array}{l}\text { Comfortable } \\
\text { with light used } \\
\text { for study }\end{array}$} \\
\hline Yes & $235(78.3)$ & $166(70.6)$ & \multirow{2}{*}{0.03} \\
\hline No & $65(21.7)$ & $37(56.9)$ & \\
\hline \multicolumn{4}{|l|}{$\begin{array}{l}\text { Type of light } \\
\text { used while } \\
\text { studying. }\end{array}$} \\
\hline Bulb & $50(16.7)$ & $36(72)$ & \multirow{3}{*}{0.71} \\
\hline Tube light & $113(37.7)$ & $74(65.5)$ & \\
\hline LED light & $137(45.7)$ & $93(67.9)$ & \\
\hline \multicolumn{4}{|l|}{$\begin{array}{l}\text { Mobile Use per } \\
\text { day }\end{array}$} \\
\hline $1-2$ hours & $49(16.3)$ & $23(46.9)$ & \multirow{3}{*}{0.001} \\
\hline $2-3$ hours & $89(29.7)$ & $59(66.3)$ & \\
\hline $\begin{array}{l}\text { More than } 3 \\
\text { hours }\end{array}$ & $162(54)$ & $121(74.7)$ & \\
\hline \multicolumn{4}{|l|}{$120-111(37 \%)$} \\
\hline 100 & & & \\
\hline 80 & $71(23.7 \%)$ & & \\
\hline 60 & & & \\
\hline 40 & & $21(7 \%)$ & \\
\hline 20 & & & \\
\hline $0 \quad$ Myopia & Hypermetropia & Astigmatism & \\
\hline
\end{tabular}

Fig 1: Types of refractive errors

\section{Discussion}

This study estimated that about 203 (67.7\%) undergraduate students of Akhtar Saeed Medical \& Dental College have refractive errors. The finding is comparable to a study carried out in India, in which 
prevalence of refractive error was estimated to be $70.7 \%$ among medical students. ${ }^{13}$ Another study conducted at West Bengal, India found that refractive errors were present in $56.9 \%$ medical students. ${ }^{14}$ High prevalence of refractive errors (68.2\%) was also observed in a study conducted at Dow Medical College, Karachi. ${ }^{15}$

Myopia was the most common refractive error reported by $111(37 \%)$ students, hypermetropia was reported by $71(23.4 \%)$ while astigmatism by $21(7 \%)$ medical students. These results are quite similar to a study conducted at Northern Border University, KSA which shows that $67.1 \%$ participants had refractive error with same order of prevalence of various refractive errors. The commonest error of refraction was observed to be myopia which was found in $53.9 \%$ subjects while hypermetropia was found in $6.6 \%$ and Astigmatism in $6.6 \%$ study participants. ${ }^{16}$ In another study conducted at Western Region of Saudi Arabia researchers found that commonest error of refraction was myopia $(40.7 \%)$ followed by hyperopia (13\%) and astigmatism (3.5\%). ${ }^{17}$

Refractive errors were more common among female students as $72.9 \%$ of female student have refractive errors as compared to $64.6 \%$ male students having refractive errors. Salih AA in his study at AlMustansiriya Medical College Iraq also described that the incidence of myopia was greater in females than in males in all cohorts. ${ }^{18}$

In this study, refractive error prevalence was highest in student having family income more than one million per month. Findings of a study conducted in Beijing also reflected higher odds $(O R=1.37)$ of myopia in students having high family income. ${ }^{19}$ Higher prevalence of refractive errors in young adults having high family income may be due to high level of $\mathrm{BMI}$, because obesity is a common occurrence in high socioeconomic groups.

Positive family history may be a contributory factor in the development of refractive error. In this study, 160 (78.8\%) students with refractive errors, reported that at least one member in their family wore glasses or use lens due to weak eye sight. Parents of $74 \%$ students who have refractive errors, use glasses or lens. In a study conducted at Karachi, positive history of refractive error was present in $72.1 \%$ participants having myopia. ${ }^{20}$ Study conducted at Nepal Medical College Kathmandu revealed somewhat different results, among total 108 students with refractive error, $90.7 \%$ told that their parents also had problem of eye sight. ${ }^{21}$ This difference may be explained on the basis of different ethnicity.

In new generation, computer and cell phones have replaced reading. Therefore, reading hours were not significantly associated with myopia in this study. It was found that mobile usage for more than 3 hours significantly increases the risk of refractive errors. Refractive errors were present in about $74.6 \%$ students who spent more than three hours in using cell phones. Similar finding was observed with use of mobile, cases were using mobile for long hours as compared to controls. ${ }^{22}$

Higher percentage of refractive error $(70.6 \%)$ was reported by participants who were comfortable with light in which they study. It reflected that students who have refractive errors are more conscious about the appropriateness of study light.

Most of the students use LED light for study, however some study in tube light and bulb light. Refractive errors are more common in those students who study in bulb light. About $72 \%$ of students who study in bulb light reported to have refractive error. Researchers described in the study conducted at Kolkata that refractive errors were more among those who used dim light like low voltage bulb while reading and less among those who study in moderate light. ${ }^{23}$

In this study refractive errors were more prevalent in those students who do exercise 3 days per week as $76 \%$ reported this. Shaik et al, described in their research that only $14.7 \%$ participants who do exercise 3 days per week while $56.5 \%$ participants who never do exercise have refractive error. ${ }^{24}$ Prevalence and associated factors may vary in different communities.

This study gives a small insight of refractive errors in medical students. However more research is still needed on a broader scale to recommend modifications in life style and environmental factors responsible for causing refractive errors.

\section{Conclusion}

Prevalence of refractive error was $67.7 \%$ among medical students, and myopia (37\%) was the most commonly reported refractory error. Refractive errors were more common in females as compared 
to males. Refractive errors were significantly associated with positive family history, high family income and mobile use per day.

\section{Acknowledgment}

The authors are thankful to Dr. Momal Khan and Asma Akif for their support and facilitation.

\section{REFERENCES}

1. Bourne RR, Flaxman SR, Braithwaite T, Cicinelli MV, Das A, Jonas JB, et al. Magnitude, temporal trends, and projections of the global prevalence of blindness and distance and near vision impairment: a systematic review and meta-analysis. Lancet Glob Health. 2017; 5: 888-97.

2. Alsaif BA, Aljindan MY, Alrammah HM, Almulla MO, Alshahrani SS. Refractive errors among Saudi college students and associated risk factors. Clin Ophthalmol (Auckland, NZ). 2019; 13: 437-43.

3. Lee MJ, Varadaraj V, Tian J, Bandeen-Roche K, Swenor BK. The Association between Frailty and Uncorrected Refractive Error in Older Adults. Ophthalmic Epidemiol. 2020; 27: 219-25.

4. Holden BA, Fricke TR, Wilson DA, Jong $M$, Naidoo KS, Sankaridurg P, et al. Global prevalence of myopia and high myopia and temporal trends from 2000 through 2050. Ophthalmol. 2016; 123: 1036-42.

5. Abbas H, Awais M, Naimat K. Prevalence and Pattern of Refractive Errors in School Going Children of Mangla Cantonment. Pak Armed Forces Med J. 2019; 69: 1125-28.

6. Hashemi H, Fotouhi A, Yekta A, Pakzad R, Ostadimoghaddam $\mathrm{H}$, Khabazkhoob M. Global and regional estimates of prevalence of refractive errors: systematic review and meta-analysis. J Curr Ophthalmol. 2018; 30: 322.

7. Abdullah AS, Jadoon MZ, Akram M, Awan ZH, Azam M, Safdar $M$, et al. Prevalence of uncorrected refractive errors in adults aged 30 years and above in a rural population in Pakistan. J Ayub Med Coll Abbottabad. 2015; 27: 8-12.

8. Kandel H, Khadka J, Goggin M, Pesudovs K. Impact of refractive error on quality of life: a qualitative study. Clin Exp Ophthalmol. 2017; 45: 677-88.

9. Honavar SG. The burden of uncorrected refractive error. Indian J Ophthalmol. 2019; 67: 577-8.

10. Garg P, Singh L, Raza M, Yadav S. Study of refractive errors in medical students. India J Clin Exp Ophthalmol. 2018; 4: 51820.

11. Naidoo KS, Fricke TR, Frick KD, Jong M, Naduvilath TJ, Resnikoff $\mathrm{S}$, et al. Potential lost productivity resulting from the global burden of myopia: systematic review, meta- analysis, and modeling. Ophthalmol. 2019; 126: 338-46.

12. Risovic DJ, Misailovic KR, Eric-Marinkovic JM, KosanovicJakovic NG, Milenkovic SM, Petrovic LZ. Refractive errors and binocular dysfunctions in a population of university students. European journal of ophthalmology. 2008; 18: 16.

13. Jyothirmai T, Meenakshi V, Padmavathi SV. A study on refractive errors among medical students attending ophthalmology department. IOSR J Dent Med Sci. 2017; 16: 57-61.

14. Dey AK, Chaudhuri SK, Jana S, Ganguly P, Ghorai S, Sarkar A. Prevalence of refractive errors in medical students. Int J Health Sci Res. 2014; 4: 98-102.

15. Economics MA, Jabir M. Refractive Errors, Eye Disorders \& Associated Risk Factors Amongst Medical Students. Ophthalmology. 2017; 15: 384.

16. Alruwaili AM, Turki Alshamdin TD, Ayad Alenzi MK, Alanazi DF, Alshammari AH, Alruwaili BK. Refractive Errors among Northern Border University Medical Students. Egypt J Hosp Med. 2018; 72: 3692-6.

17. Alghamdi $A H$, Alzahrani MA, Alhamami AS, Altalhi AK, Alkhathami AM, Alosaimi BM, et al. A study of general population awareness about refractive surgery in the Western Region of Saudi Arabia. International Journal of Medicine in Developing Countries. 2019; 3: 849-54.

18. Salih AA. Prevalence and Progression of Refractive Errors among El-Mustansiriyah Medical Students. Eurasian J Med Oncol. 2018; 2: 79-83.

19. Wu LJ, You QS, Duan JL, Luo YX, Liu LJ, Li X, et al. Prevalence and associated factors of myopia in high-school students in Beijing. PLoS One. 2015; 10: e0120764.

20. Saleem T, Eco MH, Dareshani S, Akhter M. Prevalence of Myopia and its Associated Factors amongst Medical Students of Dow University of Health Sciences, Karachi. Ophthalmology. 2017; 15: 390.

21. Rizyal A, Sunrait JS, Mishal A. Refractive errors and its associated factors among undergraduate medical students in Kathmandu. NMCJ. 2019; 21: 26-30.

22. Kumar N, Jangra B, Jangra MS, Pawar N. Risk factors associated with refractive error among medical students. Int J Community Med Public Health. 2018; 5: 634-8.

23. Basu M, Ray S, Mazumdar M, Gupta AK, Sengupta P, Chatterjee $S$. Refractive Errors and its Determinants among Medical Students of Kolkata: A Descriptive Study. Int. J Preventive Public Health Sci. 2016; 2: 11-7.

24. Shaik SA, Alkhayyal MA, AlHammad AK, AlOmair AM, AlFayez DI, AIMunif DS, et al. Prevalence of refractive errors and its associated factors among female students of King Saud University, Riyadh. . World J Med Surg Ophthal. 2016; 2:1-11. 